\title{
Uréter retrocava
}

\author{
Ballesteros Sampol JJ.
}

Servicio de Urología. Hospital Ntra. Sra. de la Esperanza. Barcelona.

Actas Urol Esp. 2008;32(3):368

$\mathrm{A}^{\mathrm{n}}$ nomalía de desarrollo de la vena cava inferior por la que el uréter se sitúa por detrás y, luego, por delante de dicha vena a nivel lumbar a modo de "sifón" siendo capaz de originar obstrucción urinaria de cuya intensidad dependerá la solución quirúrgica. Presente en el 1 por mil de los recien nacidos puede presentarse con dolor lumbar, ITU, hematuria o asociarse con urolitiasis.

Nuestro caso se diagnostica mediante ureteropielografía retrógrada (Fig. 1). Evidenciada la obstrucción se indica cirugía que consiste en la sección piélica y transposición uretral sin extirpar el segmento retrocavo (Figs. 2 y 3). Entendemos que tal indicación debe sustentarse en la constatación de un buen peristaltismo ureteral de la zona conflictiva que, en algunos caos, puede estar atrésica y obligar a su exéresis.

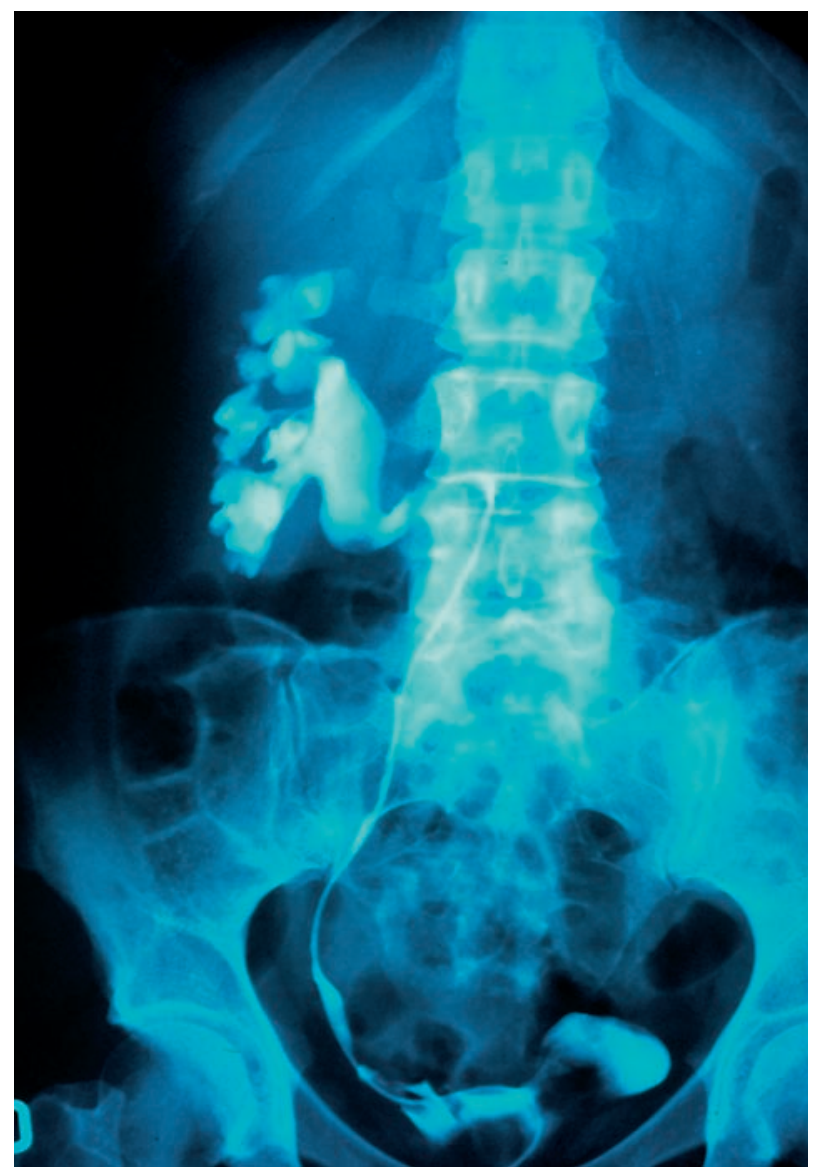

FIGURA 1

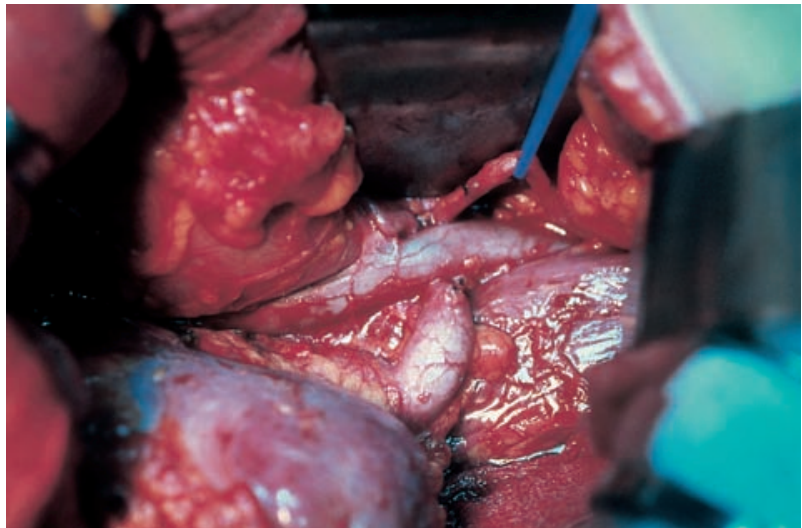

FIGURA 2

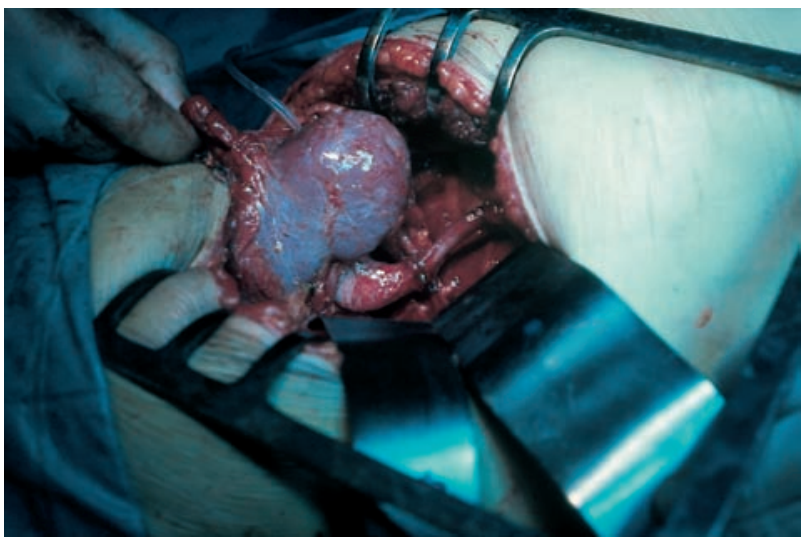

FIGURA 3

En la actualidad se ha demostrado que es una buena indicación para el acceso laparoscópico ${ }^{1}$.

\section{REFERENCIAS}

1. Sinforoosh $\mathrm{N}$ et al. Laparoscopic pyelopyelostomy for retrocaval ureter without excision of the retrocaval segment: Firts report of 6 cases. J.Urol. 2006; 175:2166-2169.

Correspondencia autor: Dr. J.J. Ballesteros Sampol Servicio de Urología. Hospital Ntra. Sra. de la Esperanza Sant Josep de la Muntanya, 12 - 08024 Barcelona Tel.: 933674100

E-mail autor: JBallesteros@imas.imim.es Información artículo: Imágenes en Urología Trabajo recibido: octubre 2006

Trabajo aceptado: noviembre 2006 